\title{
Geologi Pesisir Selatan Cianjur - Garut, Jawa Barat : Keragaman Dan Prospeknya Sebagai Obyek Geowisata
}

\author{
Agustina Djafar ${ }^{1 *}$ Ifan Yoga Pratama Suharyogi ${ }^{1}$, Johan Budi Winarto ${ }^{1}$
}

${ }^{1}$ Museum Geologi, Badan Geologi, Kementerian Energi dan Sumberdaya Mineral

\begin{abstract}
Abstrak
Pesisir selatan Cianjur-Garut secara fisiografi termasuk ke dalam zona Pegunungan Selatan Jawa Barat yang memanjang dari Teluk Pelabuhan Ratu sampai dengan Pulau Nusakambangan. Daerah pesisir tersebut menempati wilayah yang sempit yang dibatasi oleh deretan pegunungan di sebalah utara. Pantai -pantai yang terdapat di sepanjang pesisir tersebut selain memiliki panorama indah juga memiliki beberapa keragaman geologi, akan tetapi belum dikembangkan secara optimal sebagai obyek wisata. Tujuan dari pembuatan makalah ini adalah untuk mengidentifikasi keragaman geologi yang terdapat di pesisir selatan Cianjur-Garut dan menentukan peringkat atau status keragaman geologi tersebut menurut hirarkinya, untuk selanjutnya direkomendasikan pemanfaatannya sebagai obyek geowisata. Metode yang digunakan adalah pengumpulan data lapangan dan analisis data secara kualitatif, yaitu identifakasi keragaman geologi berdasarkan PP No.13 Tahun 2017, penentuan status hirarki dan peringkat keragaman geologi berdasarkan pemanfaatannya (scientific value). Keragaman geologi yang dijumpai di daerah penelitian berupa keragaman bentang alam (pantai dan gumuk pasir) dan keragaman batuan (submarine pyroclastic deposit). Bentang alam pantai dan submarine pyroclastic deposit dapat dijumpai di daerah Cidaun-Cianjur, dan Caringin-Garut, sedangkan gumuk pasir terhampar di sepanjang garis pantai Cidaun-Cianjur. Keragaman geologi tersebut memiliki status hirarki tinggi dengan nilai scientific tinggi karena mengandung rekaman ilmiah, tatanan geologi atau bentang alam yang spesifik, yang dapat dimanfaatkan untuk penelitian, pendidikan, pemahaman alam dan konservasi.
\end{abstract}

Kata kunci: geowisata; keragaman batuan; keragaman geologi; keragaman bentang alam; pesisir selatan

\begin{abstract}
Physiographically, the southern coast of Cianjur - Garut is included in the southern mountain zone of West Java. This southern mountain extends from Pelabuhan Ratu Bay in the west to Nusakambangan Island in the east. This coastal area is in a narrow area bordered by mountains to the north. The beaches along the coastline have beautiful scenery and some geodiversity that have not yet developed optimally as a tourism object. The purposes of this research were to identify and determine the geodiversity's status in the southern coast of Cianjur - Garut according to their hierarchy. Henceforth, it was recommended to use it as a geotourism object. The methods for the research were collecting data in the fields and analyzing data qualitatively. These means identification of geological diversities based on PP No.13 ${ }^{\text {th }} 2017$, about hierarchy status determination and the level of geodiversity based on its scientific value. The geological diversities encountered in the research area are landscapes diversity (beaches and sand dunes) and rock diversity (submarine pyroclastic deposit), Coastal landscapes and submarine pyroclastic deposits can be found in the Cidaun-Cianjur, and Caringin-Garut areas, while sand dunes lie along the Cidaun - Cianjur coastline. These diversities have a high level of hierarchy with high scientific value because it contains scientific records, geological arrangements or specific landscape, that can be used for research, education, understanding of nature and conservation.
\end{abstract}

Keywords: geotourism; rock diversity; geodiversity; landscapes diversity; southern coast

*) Korespondensi: agustinadjafar@gmail.com

Diajukan : 8 Februari 2021

Diterima : 6 Mei 2021

Diterbitkan : 31 Juli 2021 


\section{PENDAHULUAN}

Seiring maraknya antusias masyarakat akan sosial media, kebutuhan masyarakat terhadap wisata alam ikut berkembang pesat. Hal tersebut dapat dilihat dengan banyaknya obyek wisata swafoto dengan berlatar belakang panorama alam.

Panorama bentang alam pada suatu daerah tidak lepas dari proses dan evolusi geologi yang membentuknya. Proses dan evolusi geologi tersebut menjadi faktor penting dalam melakukan pengelompokan keragaman geologi, berdasarkan bentukan bentang alam dan hasil yang diakibatkan oleh proses tersebut.

Keragaman geologi adalah gambaran dari keragaman komponen geologi yang terdapat di suatu daerah, termasuk keberadaan, penyebaran dan keadaannya, sehingga dapat mewakili proses evolusi geologi dari daerah tersebut (Samodra, 2016). Komponen geologi terdiri dari mineral, batuan, fosil, struktur geologi, dan bentang alam, dan tidak termasuk unsur lainnya seperti iklim dan tata guna lahan.

Keragaman geologi yang dimiliki suatu daerah merupakan kekayaan hakiki, karena keragaman tersebut menjadi bukti ilmiah atau rekaman suatu peristiwa geologi yang pernah atau sedang terjadi di daerah tersebut. Untuk melindungi keragaman geologi tersebut dari bahaya anthropogene, perlu perubahan paradigma berfikir dari ekstraksi ke konservasi.
Salah satunya adalah melalui kegiatan wisata yang berbasis edukasi geologi, atau yang umum dikenal dengan istilah geowisata.

Istilah Geowisata pertama kali diperkenalkan oleh Hose di Inggris pada tahun 1995. Geowisata dikembangkan sebagai konsekuensi logis dari keprihatinan para ahli geologi yang kehilangan informasi geologi penting. Batuan dan bentang alam yang memiliki makna ilmiah rusak karena munculnya kegiatan-kegiatan yang bersifat ekstraktif, seperti penambangan, pembangunan infrastruktur berskala besar, yang mengesampingkan aspek konservasi. Geowisatapun selanjutnya dipublikasikan secara luas (Hose, 1995), dan dipakai sebagai alat promosi kegiatan geokonservasi secara berkelanjutann (Samodra, 2016).

Salah satu daerah yang memiliki keragaman geologi yang prospek untuk dikembangkan sebagai obyek geowisata adalah pesisir selatan Cianjur - Garut. Pesisir selatan Cianjur - Garut secara fisiografi termasuk ke dalam zona Pegunungan Selatan Jawa Barat yang memanjang dari Teluk Pelabuhan Ratu sampai dengan Pulau Nusakambangan. Daerah pesisir tersebut menempati wilayah yang sempit yang dibatasi oleh deretan Pegunungan Selatan Jawa bagian barat di sebelah utara (Gambar 1).

Keindahan pantai di daerah ini tidak kalah menarik dengan pantai-pantai di pesisir selatan Yogyakarta - Jawa Tengah - Jawa Timur, akan

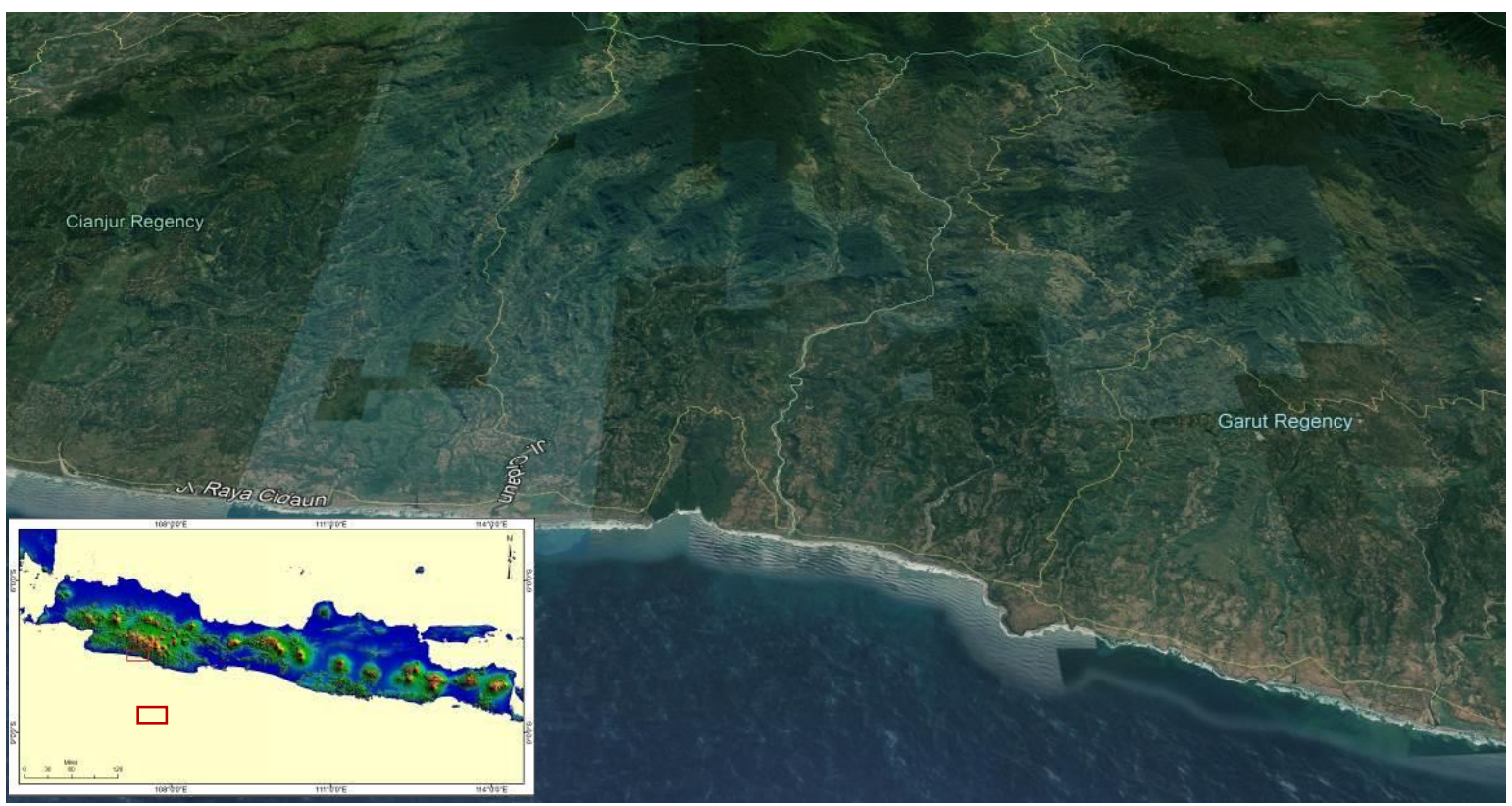

Gambar 1. Lokasi penelitian yang mencakup pesisir selatan Cianjur-Garut, Jawa Barat. 
tetapi belum dikembangkan secara optimal sebagai obyek wisata, bahkan masih kurang dikenal baik oleh wisatawan lokal maupun dari luar. Hal tersebut dapat dilihat dari jumlah wisatawan yang berkunjung ke daerah tersebut masih kurang jika dibandingkan dengan pantaipantai di Yogyakarta - Jawa Tengah - Jawa Timur.

Tujuan dari pembuatan makalah ini adalah untuk mengidentifikasi keragaman geologi yang terdapat di pesisir selatan Cianjur Garut dan menentukan peringkat atau status keragaman geologi tersebut menurut hirarkinya, untuk selanjutnya direkomendasikan pemanfaatannya sebagai obyek geowisata.

\section{DATA DAN METODE}

Menurut van Bemmelen (1949), pesisir selatan Cianjur - Garut secara fisiografi termasuk dalam zona Pegunungan Selatan Jawa bagia barat, dan menurut tatanan karakter sedimen dan tektoniknya (Martodjojo, 1984) termasuk dalam blok Pegunungan Selatan Jawa Barat. Adapun batuan yang menyusun daerah penelitian berdasarkan peta geologi Lembar Sindangbarang dan Bandarwaru (Koesmono, dkk., 1996) berupa alluvial dan endapan pantai, dan runtutan turbidit berupa batupasir tuf, tuf kristal, tuf batuapung dengan sisipan batulempung, batulanau, breksi andesit, konglomerat, tuf lapilli dan breksi lapilli Formasi Bentang (Tmb), yang diperkirakan berumur Miosen Atas.

Metode yang digunakan dalam penelitian ini adalah pengumpulan data lapangan dan analisis data secara kualitatif. Pengumpulan data dilakukan dengan mengenali, mengamati dan mendeskripsi keragaman geologi yang dijumpai di lokasi penelitian, serta pengambilan data koordinat dan dokumentasi foto. Setelah itu dilakukan analisis data berupa karakterisasi dan pengelompokan keragaman geologi berdasarkan PP No.13 Tahun 2017, penentuan status hirarki dan peringkat geodiversity berdasarkan pemanfaatannya (scientific value).

Klasifikasi untuk menentukan peringkat atau status geodiversity menurut hirarki dilakukaan dengan menggunakan parameter (a) bentang alam umum, (b) ranah batuan atau mintakat geologi, (c) proses internal dan eksternal, (d) tektonik, dan (e) evolusi temporer (Samodra, 2016) (Tabel 1). Berdasarkan parameter tersebut, klsifikasi peringkat atau status geodiversity, adalah:

Tabel 1. Parameter penentuan peringkat atau status geodiversity menurut hirerki (Samodra, 2016).

\begin{tabular}{|c|c|c|c|c|}
\hline \multicolumn{5}{|c|}{ Parameter } \\
\hline $\begin{array}{c}\text { (a) } \\
\text { Bentang alam } \\
\text { Umum }\end{array}$ & $\begin{array}{c}\text { (b) } \\
\text { Ranah Batuan atau } \\
\text { Mintakat geologi }\end{array}$ & $\begin{array}{c}\text { (c) } \\
\text { Proses Internal dan Eksternal }\end{array}$ & $\begin{array}{l}\text { (d) } \\
\text { Tektonik }\end{array}$ & $\begin{array}{l}\text { (e) } \\
\text { Evolusi Temporer }\end{array}$ \\
\hline $\begin{array}{l}\text { Pegunungan } \\
\text { (pematang, } \\
\text { plato), } \\
\text { perbukitan } \\
\text { (pematang, } \\
\text { plato, } \\
\text { bergelombang), } \\
\text { dataran (sungai, } \\
\text { pantai), } \\
\text { kepulauan } \\
\text { (gugusan, pulau } \\
\text { tunggal, pulau } \\
\text { terisolir), kars, } \\
\text { dan gunungapi }\end{array}$ & $\begin{array}{l}\text { Jenis-jenis batuan } \\
\text { seperti batuan beku } \\
\text { (plutonik, vulkanik, } \\
\text { ultramafik, } \\
\text { hipabisal), batuan } \\
\text { sedimen (klastik } \\
\text { pejal, klastik berlapis, } \\
\text { batugamping, } \\
\text { evaporit, sedimen } \\
\text { yang belum } \\
\text { terbatukan), batuan } \\
\text { malihan (pejal, } \\
\text { mendaun, fasies), } \\
\text { mintakat geologi } \\
\text { antara lain blok } \\
\text { batuan akibat } \\
\text { tektonik dan bancuh- } \\
\text { tunjaman (melange) }\end{array}$ & $\begin{array}{l}\text { Pengangkatan (disebabkan oleh } \\
\text { tektonik, plutonisma, diaprisma, } \\
\text { isostatik), mampatan (terkumpul } \\
\text { di batas lempeng tektonik), } \\
\text { pensesaran, rifting (terjadi di } \\
\text { batas lempeng tektonik), dan } \\
\text { vulkanisme (peletusan, aliran } \\
\text { material gunungapi); proses } \\
\text { eksternal antara lain pelapukan } \\
\text { (fisika, kimia), pengikisan (oleh } \\
\text { air, angin, gelombang, es, } \\
\text { biogenik), pelarutan (oleh air), } \\
\text { pengendapan (terjadi di lereng, } \\
\text { sungai, danau, rawa, pantai, } \\
\text { laut), gerakan massa batuan/ } \\
\text { tanah (jatuhan, longsoran, } \\
\text { rayapan), dan benda jatuhan dari } \\
\text { angkasa/ extra-terrestrial } \\
\text { (meteorit, tektit) }\end{array}$ & $\begin{array}{l}\text { Tektonik } \\
\text { dapat } \\
\text { bersifat } \\
\text { masih aktif } \\
\text { (labil) atau } \\
\text { sudah tidak } \\
\text { aktif } \\
\text { (stabil) }\end{array}$ & $\begin{array}{l}\text { Umur geologi } \\
\text { (Prakambrium, } \\
\text { Paleozoikum, } \\
\text { Mesozoikum, } \\
\text { Tersier, Kuarter; } \\
\text { termasuk bagian- } \\
\text { bagiannya), derajat } \\
\text { kematangan evolusi } \\
\text { (tua, menengah, } \\
\text { muda), dan tipe } \\
\text { (statis, aktif) }\end{array}$ \\
\hline
\end{tabular}


1) Geodiversity berstatus rendah, hanya mempunyai parameter (a);

2) Geodiversity berstatus sedang, mempunyai parameter (a)+(b);

3) Geodiversity berstatus tinggi, mempunyai parameter (a)+(b)+(c);

4) Geodiversity berstatus sangat tinggi, mempunyai (a)+(b)+(c)+(d);

5) Geodiversity berstatus terkemuka, mempunyai $(a)+(b)+(c)+(d)+(e)$.

\section{HASIL DAN PEMBAHASAN}

Identifikasi keragaman geologi yang terdapat di pesisir selatan Cianjur - Garut berdasarkan Peraturan Pemerintah No 13. Tahun 2017 tentang Rencana Tata Ruang Wilayah, meliputi keragaman bentang alam dan keragaman batuan.

\section{A. Keragaman Bentang Alam}

Keragaman bentang alam di daerah penelitian berupa, bentang alam pantai, dan gumuk pasir.

\section{Bentang alam pantai}

Di pesisir selatan Cianjur-Garut terdapat pedataran alluvial pantai, yang beberapa diantaranya telah menjadi obyek wisata yaitu Pantai Jayanti - Cianjur dan Pantai Rancabuaya Garut. Seperti pantai lainnya di pesisir selatan Jawa, pantai-pantai tersebut memiliki ombak yang tinggi dan arus yang deras. Namun jika dibandingkan dengan kepopuleran pantai-pantai selatan yang ada di Yogyakarta - Jawa Tengah Jawa Timur, pantai di daerah ini masih kurang dikunjungi oleh wisatawan.

Pantai Jayanti terletak di Desa Cidamar, Kecamatan Cidaun, Kabupaten Cianjur. Lokasi pantai ini cukup strategis dan aksesnya sangat mudah dijangkau. Pantai ini cukup terkenal di kalangan Masyarakat Cianjur, karena adanya mitos yang berkembang bahwa, konon dahulu kala pantai ini pernah menjadi tempat persinggahan Prabu Siliwangi yang ditandai dengan adanya lubang pada permukaan batuan (pothole) yang menyerupai jejak, yang oleh masyarakat setempat dianggap sebagai jejak kaki dari Prabu Siliwangi. Selain itu, pantai ini memiliki keindahan lain berupa sisi pantai yang menjorok di sebelah barat yang digunakan oleh masyarakat setempat sebagai tempat keluar masuknya perahu dan tambatan perahu.

Pantai Jayanti merupakan pantai berpasir dan berbatu. Sebelah timur Pantai Jayanti merupakan

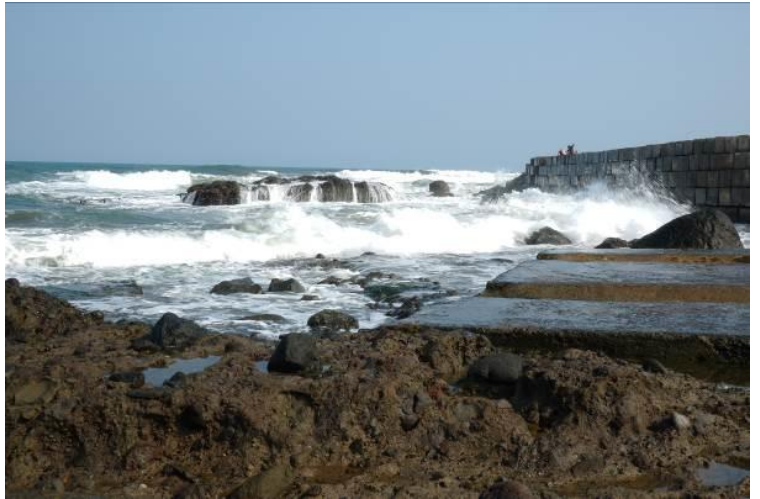

Gambar 2. Sisi barat Pantai Jayanti, yang merupakan pantai berbatu dengan batuan penyusun berupa konglomerat polimik.

pantai berpasir hitam, dengan bangunan pemecah ombak sepanjang kurang lebih $75 \mathrm{~m}$, tinggi sekitar $3 \mathrm{~m}$. Bangunan pemecah ombak tersebut berfungsi untuk mencegah terjadinya abrasi sepanjang garis pantai. Sebelah barat merupakan pantai berbatu, dengan batuan penyusun berupa breksi polimik dengan fragmen berupa basal, andesit dan tuf batuapung, serta matriks berupa batupasir tufaan berukuran sedang $(1 / 4-1 / 2 \mathrm{~mm})$. Batuan tersebut merupakan anggota Formasi Bentang (Tmb) berumur Miosen Atas (Gambar 2).

Pantai Rancabuaya terletak di Desa Purbayani, Kecamatan Caringin, Kabupaten Garut. Pantai ini memiliki letak yang strategis dan mudah untuk dijangkau, karena terletak di pinggir jalan poros Garut Selatan - Pangandaran. Pantai ini memiliki bentukan tebing yang sedikit menjorok ke tengah laut dengan hamparan pasir putih, dan hamparan ombak yang tinggi dan arus yang deras yang makin memperindah panorama pantai ini.

Pantai ini terdiri dari pantai berbatu (sebelah timur) dan pantai berpasir (sebelah barat). Pantai berbatu Rancabuaya tersusun dari perlapisan batuan breksi yang mengandung fragmen basal, andesit, dan setempat dijumpai arang (charcoal), batupasir tuf dan bagian atas berupa batugamping terumbu (Gambar 3a). Kehadiran batugamping terumbu menunjukkan bahwa garis pantai yang ada saat ini mengalami pergeseran (mundur) ke arah laut. Selain itu pada permukaan konglomerat dan batupasir tuf dijumpai potholes, yaitu lubang pada permukaan batuan yang terbentuk akibat pengikisan oleh air (Gambar 3b).

Pada sisi barat pantai berbatu Rancabuaya, terdapat tebing batuan setinggi 8 meter, yang 

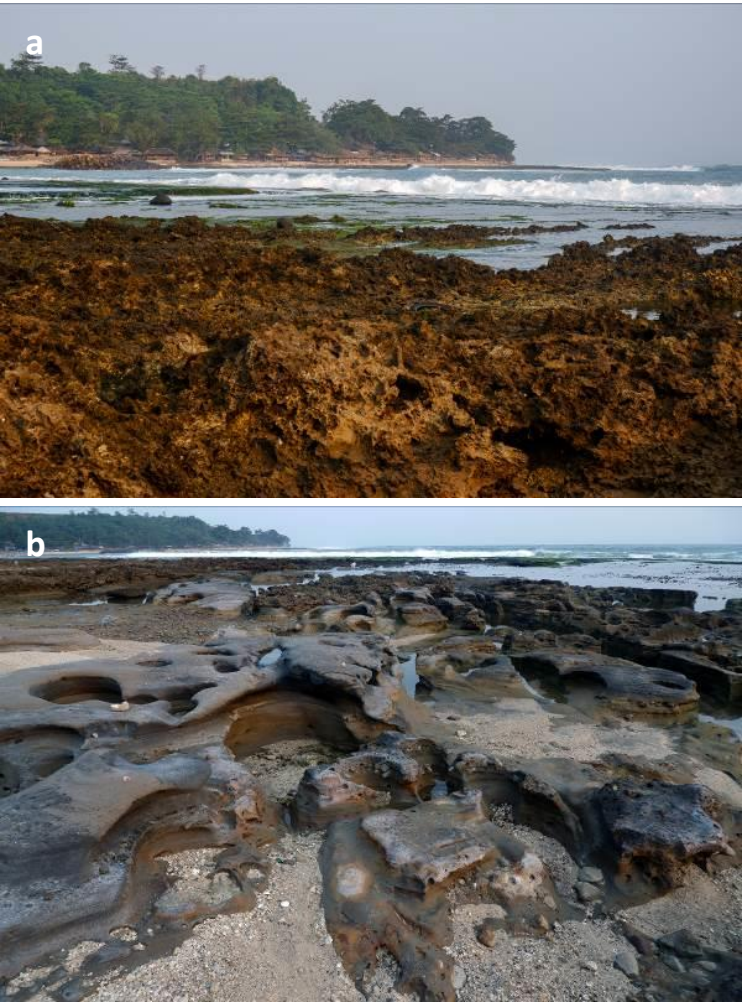

Gambar 3. (a) Kenampakan singkapan batugamping terumbu, dan (b) potholes pada permukaan batupasir tuf di Pantai Rancabuaya.

tersusun dari perlapisan (dari bawah ke atas):batuan breksi, batupasir tuf, dan breksi breksi, dengan struktur sedimen laminasi (N $25^{\circ} \mathrm{E} / 5^{\circ}$ ) dan coarsening upward. Berdasarkan peta geologi Lembar Sindangbarang dan Bandarwaru (Koesmono dkk., 1996), batuan yang menyusun daerah ini merupakan anggota Formasi Bentang (Tmb), yang berumur Miosen Atas.

Keindahan pantai di pesisir selatan Cianjur Garut, akan semakin indah pada saat matahari terbenam (Gambar 4). Selain panorama senja dan keragaman batuannya, kenampakan bentang alam pantai di pesisir selatan Cianjur - Garut, terlihat indah dan menarik jika dilihat dari ketinggian. Salah satu lokasi titik pandang tersebut adalah tanah lapang depan Mesjid AlJabbar Desa Karangwangi, Kecamatan Mekarmukti, Garut (Gambar 5). Dari titik pandang ini, wisatawan dapat melihat keindahan panorama Pantai Cicalobak-Rancabuaya dari kejauhan.

\section{Gumuk Pasir Cidaun}

Gumuk pasir secara harfiah diartikan sebagai

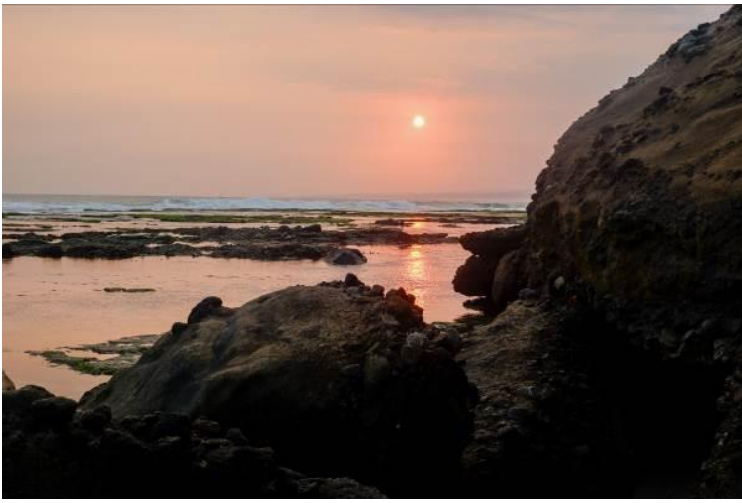

Gambar 4. Kenampakan dinding batuan di sisi barat Pantai Rancabuaya, berlatar panorama senja.

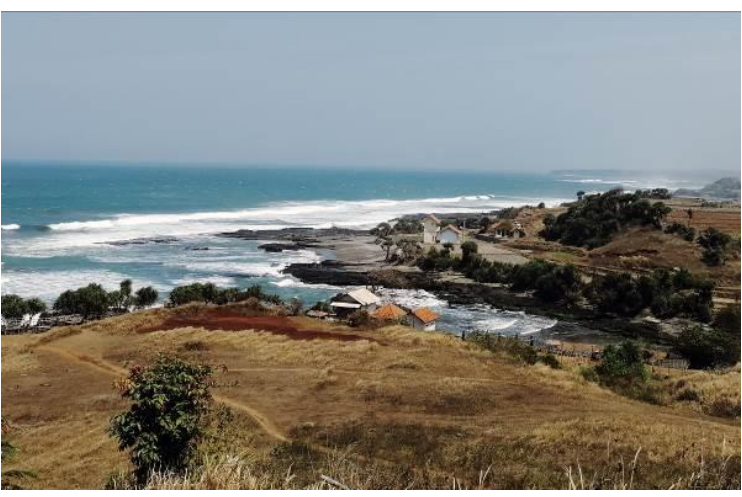

Gambar 5. Keindahan Pantai Cicalobak Rancabuaya, dari titik pandang Mesjid Al Jabbar Garut Selatan.

gundukan pasir menyerupai bukit kecil. Gumuk pasir umumnya terbentuk pada daerah gurun, namun uniknya di Indonesia yang beriklim tropis dengan curah hujan yang tinggi terdapat bentukan gumuk pasir tersebut. Selama ini keberadaan gumuk pasir di Indonesia hanya diketahui terdapat di daerah Kulon Progo - Yogyakrata, keberadaan gumuk pasir di daerah Cidaun Cianjur belum dikenal oleh masyarakat umum.

Gumuk pasir merupakan bentukan yang dihasilkan oleh aktivitas angin (eolian). Gumuk pasir dapat berkembang dengan baik apabila tersedia material berukuran pasir halus hingga kasar dalam jumlah yang banyak, periode kering yang panjang dan tegas, angin yang mampu mengangkut dan mengendapkan bahan pasir tersebut, dan gerakan angin tidak banyak terhalang oleh vegetasi maupun obyek lain.

Gumuk pasir di sepanjang pantai Cidaun memiliki arah sebaran relatif timur-barat (Gambar 6), yang berdasarkan hasil perhitungan di google earth memiliki panjang sekitar \pm 7 kilometer dengan lebar sekitar $\pm 90-120$ meter. 
Terbentuknya gumuk pasir di pesisir selatan Jawa Barat merupakan hasil proses yang dipengaruhi oleh aktifitas angin muson tenggara, material pasir dan piroklastik lainnya yang kemungkinan berasal dari hasil erupsi gunungapi purba di sebelah utara, diantaranya Gunung Patuha dan Gunung Kendeng, serta beberapa aliran sungai besar yang bermuara di pesisir selatan Cianjur yaitu Ci Royom Gede, Ci Damar, Cibodas dan Cikaso, yang mengalirkan material tersebut ke pesisir selatan (Gambar 7).

Pada pantai selatan Jawa Barat, angin bertiup dari arah tenggara, hal ini menyebabkan sungaisungai pada pantai selatan membelok ke arah kiri jika dilihat dari Samudra Hindia. Selain itu, karena arah tiupan angin yang berarah relatif tenggara - barat laut, maka gumuk pasir yang terbentuk di daerah Cidaun menghadap ke arah datangnya angin. Kecepatan angin yang cukup tinggi mampu memindahkan butiran-butiran ukuran pasir yang dihempaskan oleh kekuatan gelombang laut ke lingkungan pantai, sehingga terbentuk gundukan-gundukan pasir lepas.

\section{B. Keragaman Batuan}

Keragaman batuan yang dijumpai di pesisir selatan Cianjur - Garut, adalah submarine pyroclastic deposit. Evolusi geologi regional Jawa Barat di mulai sejak Jaman Kapur Akhir dan mengalami aktivitas tektonik tinggi pada Jaman Intra Miosen (van Bemmelen, 1949) dan terus berlanjut sampai saat ini. Kegiatan tektonik yang diperkirakan terjadi pada Oligo-Miosen tersebut memicu terjadinya kegiatan volkanik laut dalam dan terbuka yang menghasilkan Formasi Jampang (Tmoj) dan Formasi Bentang (Tmb). Dinamika tersebut menjadi salah satu bukti bahwa dahulu Jawa Barat Selatan merupakan bagian dari busur gunungapi (volcanic arc) yang dicirikan oleh hasil produk gunungapi tua (Formasi Andesit Tua) (van Bemmelen, 1949).

Batuan yang merupakan produk piroklastik vulkanik bawah laut di sepanjang pesisir selatan Cianjur - Garut tersingkap dengan baik di Pantai Jayanti - Cianjur dan Pantai Rancabuaya - Garut. Batuan penyusun Pantai Jayanti berupa breksi polimik dengan fragmen berupa basal, andesit dan tuf batuapung, matriks berupa batupasir tufaan berukuran sedang $(1 / 4-1 / 2 \mathrm{~mm})$. Batuan penyusun Pantai Rancabuaya tersusun dari perlapisan batuan breksi yang mengandung fragmen basal, andesit, batuapung, dan setempat dijumpai arang (charcoal), batupasir tuf dan bagian atas berupa breksi. Berdasarkan Peta Geologi Lembar Sindangbarang dan Bandarwaru (Koesmono, dkk., 1996) batuan penyusun daerah ini termasuk dalam Formasi Bentang (Tmb) berumur Miosen akhir.

Pusat kegiatan gunungapi bawah laut pada umumnya terdapat di sepanjang sistem rekahan dasar laut yang berasosiasi dengan tektonik di daerah tersebut, dan produknya pun bermacammacam, dapat berupa: lava bantal (pillow lava),

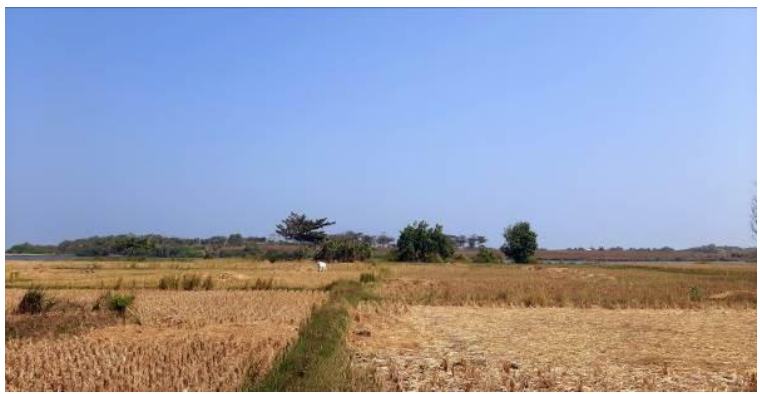

Gambar 6. Kenampakan gumuk pasir Cidaun, dengan arah sebaran relatif timur barat.

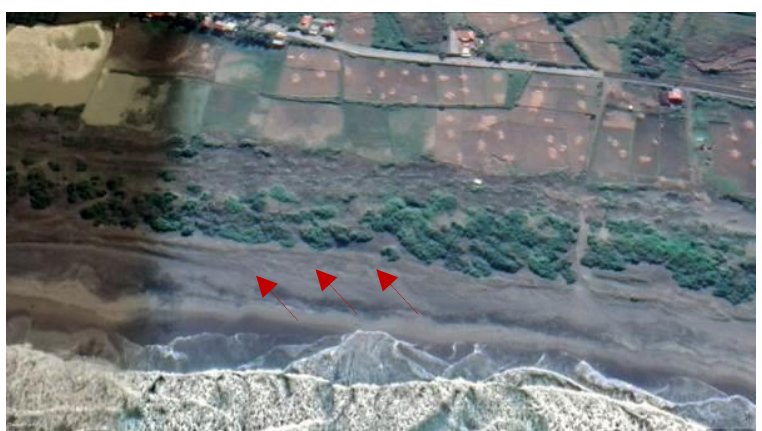

Gambar 7. Citra landsat gumuk pasir Cidaun yang menunjukkan adanya pengaruh angin muson tenggara. (Sumber: google earth, September 2018).

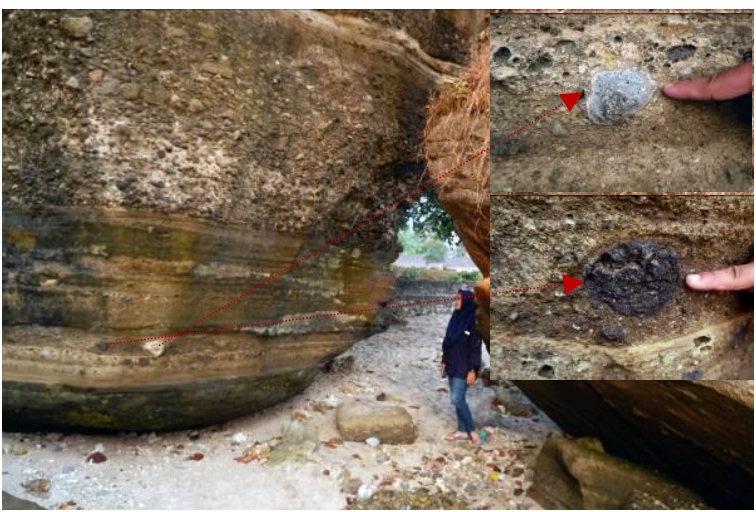

Gambar 8. Kenampakan singkapan submarine pyroclastic deposits (inverse gradded bedding) dengan fragmen berupa basal dan batuapung, yang memperlihatkan tekstur kaca. 


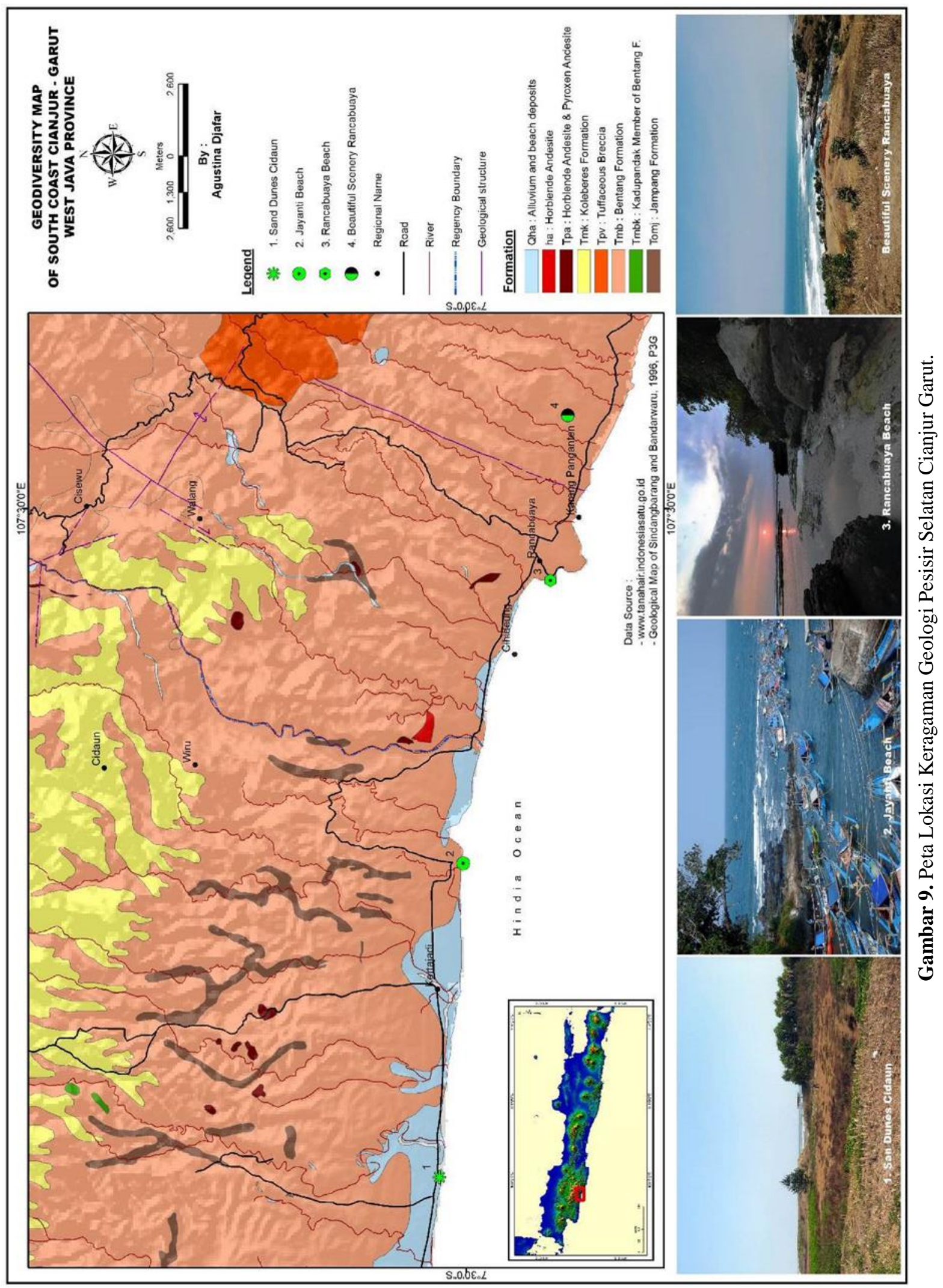


peperit, breksi hialoklastik, dan struktur sedimen berupa inverse gradded bedding. Produk-produk yang dihasilkan tersebut terbentuk sebagai akibat fragmentasi dari deferensasi magma yang disertai oleh interaksi antara lava dengan air atau sedimen yang jenuh air.

Penciri endapan piroklastik bawah laut (submarine pyroclastic deposit) di daerah ini, dapat dilihat dari struktur sedimen pada perlapisan batuan yang tersingkap pada tebing Pantai Rancabuaya berupa inverse graded bedding (Gambar 8), dan fragmen batuan (breksi hialokastik) yang memperlihatkan tekstur kaca (glassy skin) pada bagian pinggir fragmen sehingga menyerupai kulit luar (cortex), dengan bagian dalam yang memperlihatkan retakanretakan "perlitik" yang memencar (radial) (Gambar 8). Struktur rekahan radial mencerminkan terjadinya pengkerutan (kontraksi) akibat dari proses pendinginan dari hamburan material panas yang mendingin secara mendadak karena kontak dengan air.

Berdasakan hasil uraian di atas, peringkat atau status geodiversity di pesisir selatan Cianjur Garut menurut hirarkinya adalah tinggi, karena mempunyai parameter $(a)+(b)+(c)$ (Tabel 2). Peringkat keragaman geologi di pesisir selatan Cianjur - Garut berdasarkan manfaatnya (scientific value) memiliki nilai tinggi karena mengandung rekaman ilmiah, tatanan geologi atau bentang alam yang spesifik, yang dapat dimanfaatkan untuk penelitian, pendidikan, pemahaman alam dan konservasi. Selain itu dari beberapa komponen geologi yang dijumpai di daerah ini, berupa keragaman batuan dan keindahan bentang alamnya (Gambar 9), pemaknaan keragaman geologi di pesisir selatan Cianjur - Garut memiliki makna estetitika dan

Tabel 2. Penilaian peringkat atau status geodiversity di daerah penelitian.

\begin{tabular}{lccccc}
\hline \multirow{2}{*}{ Geodiversity } & \multicolumn{5}{c}{ Parameter } \\
\cline { 2 - 6 } & (a) & (b) & (c) & (d) & (e) \\
\hline $\begin{array}{l}\text { Pantai } \\
\text { Jayanti }\end{array}$ & $\mathrm{x}$ & $\mathrm{x}$ & $\mathrm{x}$ & & \\
\hline $\begin{array}{l}\text { Pantai } \\
\text { Rancabuaya }\end{array}$ & $\mathrm{x}$ & $\mathrm{x}$ & $\mathrm{x}$ & & \\
\hline $\begin{array}{l}\text { Gumuk } \\
\text { Pasir } \\
\text { Cidaun }\end{array}$ & $\mathrm{x}$ & $\mathrm{x}$ & $\mathrm{x}$ & & \\
\hline
\end{tabular}

rekreasi, sehingga sangat prospek untuk dikembangkan sebagai obyek wisata berbasis edukasi geologi (geowisata).

\section{KESIMPULAN}

Pesisir Selatan Cianjur - Garut, Jawa Barat memiliki keragaman geologi yang menarik untuk dikembangkan sebagai salah satu obyek wisata berbasis edukasi geologi (geowisata). Hal ini dapat dilihat dari keragaman bentantang alam dan batuan yang dimiliki daerah tersebut. Keragaman bentang alamnya berupa gumuk pasir, dan pantai yang memiliki panorama indah karena menghadap langsung ke Samudera Hindia. Adapun keragaman batuan berupa "submarine pyroclastic deposits".

Berdasarkan hasil penilaian dengan menggunakan beberapa parameter, peringkat atau status geodiversity di daerah ini menurut hirarkinya adalah tinggi, dengan scientific value tinggi.

\section{UCAPAN TERIMA KASIH}

Kami mengucapkan terima kasih kepada Bapak Iwan Kurniawan selaku Kepala Museum Geologi yang telah memberikan izin dalam melakukan penelitian di lokasi ini, Bapak Indyo Pratomo serta rekan-rekan di Museum Geologi yang telah memberi masukan dan membantu dalam pengumpulan data di lapangan, dan Ibu Kurnia yang telah membantu dalam fotografi panorama Pantai Cicalobak - Rancabuaya.

\section{DAFTAR PUSTAKA}

Anonim, 2017, PP NO. 21 Tahun 2017 tentang Perubahan atas PP No. 26 Tahun 2008 tentang Rencana Tata Ruang Wilayah Nasional.

Anonim, 2018, Google Earth (Online), https://earth.google.com/web/@ 7.49095368,107.28163546,4.44774829a, 3178.47065719d,35y,0h,0t,0r diakses pada September 2018.

Hose, T.A., 1995, Selling the story of Britain's stone. Environmental Interpretation, 10(2), hal.16-17.

Koesmono M., Kusnama, dan N. Suwarna, 1996. Peta Geologi Lembar Sindangbarang dan Bandarwaru Skala 1:100.000. Bandung: 
Pusat Penelitian dan Pengembangan Geologi.

Martodjojo, S. 1984. Evolusi Cekungan Bogor, Jawa Barat. Disertasi Doktor, Fakultas Pasca Sarjana Institut Teknologi Bandung.

Samodra, H., 2016. Inventarisasi Keragaman Geologi Dan Identifikasi Warisan
Geologi Untuk Keperluan Cagar Alam Geologi. Bandung: Badan Geologi.

van Bemmelen, R. W., 1949. The Geology of Indonesia, vol.1A. General Geology of Indonesia and Adjacent Archipelagoes. The Hague. 